\title{
Back to the St. Petersburg Paradox?
}

Pavlo Blavatskyy

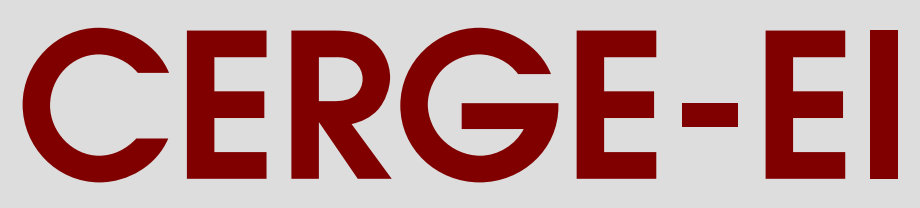

Charles University Center for Economic Research and Graduate Education Academy of Sciences of the Czech Republic Economics Institute 


\title{
Back to the St. Petersburg paradox?
}

\author{
Pavlo R. Blavatskyy ${ }^{*}$
}

\section{CERGE-EI}

\begin{abstract}
:
Conventional parameterizations of cumulative prospect theory do not explain the St. Petersburg paradox. To do so, the power coefficient of an individual's utility function must be lower than the power coefficient of an individual's probability weighting function.
\end{abstract}

\begin{abstract}
Abstrakt:
Konvenční parametrizace kumulativní prospektové teorie nevysvětlují Petrohradský paradox. K tomu je zapotřebí, aby mocnitel jedincovy užitkové funkce byl nižší než mocnitel jeho pravděpodobnostní váhové funkce.
\end{abstract}

Keywords: EUT, cumulative prospect theory, St. Petersburg paradox, power utility, probability weighting

JEL Classification codes: C91, D81

${ }^{*}$ Pavlo R. Blavatskyy, P.O.B. 882, Politickych veznu 7, Prague-1, 11121, Czech Republic Phone: +420 224005 248, Fax: +420 224227 143, E-mail: pavlo.blavatsky@cerge-ei.cz 


\section{Back to the St. Petersburg paradox?}

The St. Petersburg paradox (Bernoulli, 1738) refers to a lottery $L$ that delivers an outcome $2^{n}$ with probability $2^{-n}, n \in \grave{u}$. The maximum price that an individual is willing to pay for $L$ is finite and typically low. However, $L$ has an infinite expected value. Thus, the St. Petersburg paradox is generally taken as evidence against expected value and in favor of expected utility theory (EUT). Samuelson (1977) offers an extensive survey of the St. Petersburg paradox.

Arguably the dominant descriptive decision theory today is cumulative prospect theory or CPT (Tversky and Kahneman, 1992). CPT accommodates a large amount of experimental data including robust violations of EUT such as the Allais paradox (Allais, 1953). According to CPT an individual utility of the lottery $L$ involved in the St. Petersburg paradox is given by formula (1), where $u: \mathbf{u}_{+} \rightarrow$ ú $_{+}$is an individual's utility function for gains and $w:[0,1] \rightarrow[0,1]$ is an individual's probability weighting function for gains.

$$
u(L)=\sum_{n=1}^{+\infty} u\left(2^{n}\right)\left[w\left(2^{1-n}\right)-w\left(2^{-n}\right)\right]
$$

Following Tversky and Kahneman (1992), the majority of studies adopt a power utility function $u(x)=x^{\alpha}$ and an S-shaped probability weighting function $w(p)=p^{\gamma} /\left(p^{\gamma}+(1-p)^{\gamma}\right)^{1 / \gamma}$ first proposed by Quiggin (1982). Since the St. Petersburg paradox lottery $L$ involves very small probabilities, Quiggin's function $w(p)$ may be accurately approximated as $w(p) \approx p^{\gamma}$ because the denominator of Quiggin's function $w(p)$ converges to unity for tiny probabilities $p$. Then, equation (1) simplifies into formula (2).

$$
u(L) \approx\left(2^{\gamma}-1\right) \sum_{n=1}^{+\infty} 2^{(\alpha-\gamma) n}
$$

It follows from (2) that according to CPT an individual obtains a bounded utility from lottery $L$ only when $\alpha<\gamma$ i.e. when the sum on the right hand side of (2) is convergent. Thus, CPT 
explains the St. Petersburg paradox only when the power coefficient of an individual's utility function is lower than the power coefficient of an individual's probability weighting function. Intuitively, an individual's utility function must not simply be concave but it must be concave relative to an individual's probability weighting function to avoid the St. Petersburg paradox.

Table 1 presents typical values of power coefficients $\alpha$ and $\gamma$ that were obtained from the best parametric fitting to the experimental data in well-known recent studies. Some studies (e.g. Tversky and Fox, 1995) adopted a probability weighting function $w(p)=\delta \cdot p^{\gamma} /\left(\delta \cdot p^{\gamma}+(1-p)^{\gamma}\right)$, first used by Goldstein and Einhorn (1987). For small probabilities a Goldstein-Einhorn function $w(p)$ can be approximated as $w(p) \approx \delta \cdot p^{\gamma}$. An individual then still obtains a bounded utility from lottery $L$ only when $\alpha<\gamma$. The best fitting estimates of a power coefficient $\gamma$ for a Goldstein-Einhorn function $w(p)$ are presented in parentheses in the third column of table 1 (for those studies where applicable).

In all studies from table 1 except for Camerer and Ho (1994) and Wu and Gonzalez (1996) the estimated best fitting CPT parameters are $\alpha>\gamma$, which implies a divergent sum on the right hand side of equation (2). Thus, conventional parameterizations of CPT predict that an individual is willing to pay up to infinity for the St. Petersburg lottery $L$. This paradoxical result occurs because a conventional inverse S-shaped probability weighting function overweights small probabilities too much for a mildly concave utility function to offset this effect.

Apparently, the parameterization of CPT that accommodates best the available experimental evidence does not explain the oldest and the most famous paradox in decision theory - the St. Petersburg paradox. To accommodate the St. Petersburg paradox CPT must be estimated together with a restriction $\alpha<\gamma$ on its parameters. However, it is not obvious if a restricted version of CPT remains descriptively superior to other decision theories. 


\begin{tabular}{|l|l|l|}
\hline \multicolumn{1}{|c|}{ Experimental study } & \multicolumn{1}{|c|}{$\begin{array}{c}\text { Power of utility function } \\
\text { (alpha) }\end{array}$} & $\begin{array}{c}\text { Power of probability } \\
\text { weighting function } \\
\text { (gamma) }\end{array}$ \\
\hline Kahneman and Tversky (1992) & 0.88 & 0.61 \\
\hline Camerer and Ho (1994) & 0.37 & 0.56 \\
\hline Tversky and Fox (1995) & 0.88 & $0.71(0.68)$ \\
\hline Wu and Gonzalez (1996) & 0.52 & $0.60(0.60)$ \\
\hline Abdellaoui (2000) & 0.89 & $0.67(0.55)$ \\
\hline Bleichrodt and Pinto (2000) & 0.77 & $(0.30-0.51)$ \\
\hline Kilka and Weber (2001) & $0.76-1.00$ & $(0.76)$ \\
\hline Abdellaoui et al. (2003) & 0.91 & \\
\hline
\end{tabular}

Table 1 Parameterization of CPT that accommodates best the experimental data in wellknown recent studies 


\section{References:}

Abdellaoui, M., 2000, Parameter-free elicitation of utility and probability weighting functions, Management Science 46, 1497-1512.

Abdellaoui, M., F. Vossmann, and M. Weber, 2003, Choice-based elicitation and decomposition of decision weights for gains and losses under uncertainty, CEPR DP 3756.

Allais, M., 1953, Le comportement de l'homme rationnel devant le risque: critique des postulates et axiomes de l'école Américaine, Econometrica 21, 503-546.

Bernoulli, D., 1738, Specimen theoriae novae de mensura sortis, Commentarii Academiae Scientiarum Imperialis Petropolitanae, translated as Bernoulli, D., 1954, Exposition of a new theory on the measurement of risk, Econometrica 22, 23-36.

Bleichrodt, H. and J. Pinto, 2000, A parameter-free elicitation of the probability weighting function in medical decision analysis, Management Science 46, 1485-1496.

Camerer, C. and T. Ho, 1994, Violations of the Betweenness Axiom and Nonlinearity in Probability, Journal of Risk and Uncertainty 8, 167-196

Goldstein, W. and H. Einhorn, 1987, Expression theory and the preference reversal phenomena, Psychological Review 94, 236-254.

Kilka, M. and M. Weber, 2001, What determines the shape of the probability weighting function under uncertainty?, Management science 47, 1712-1726

Quiggin, J., 1982, A Theory of Anticipated Utility, Journal of Economic Behaviour and Organization 3, 323-343.

Samuelson, P., 1977, St. Petersburg paradoxes: defanged, dissected, and historically described, Journal of Economic Literature 15, 24-55.

Tversky, A. and C. Fox, 1995, Weighing risk and uncertainty, Psychological Review 102(2), 269283.

Tversky, A. and D. Kahneman, 1992, Advances in Prospect Theory: Cumulative Representation of Uncertainty, Journal of Risk and Uncertainty 5, 297-323.

Wu, G. and R. Gonzalez, 1996, Curvature of the probability weighting function, Management Science 42, 1676-90. 
CERGE-EI

P.O.BOX 882 Politických vezòù 7

11121 Prague 1

Czech Republic http://www.cerge-ei.cz 